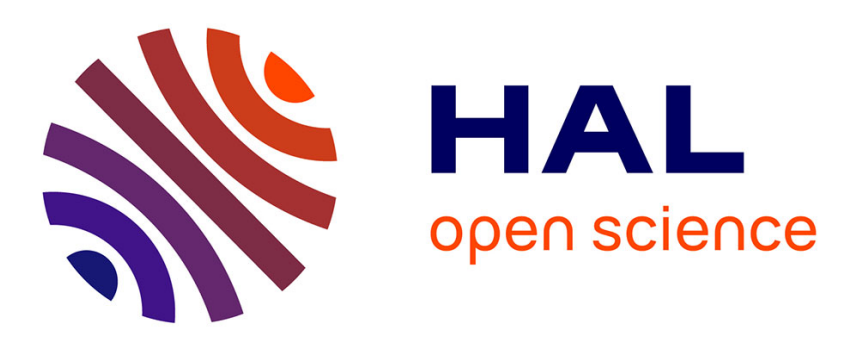

\title{
The Patent System during the French Industrial Revolution: Institutional Change and Economic Effects Gabriel Galvez-Behar
}

\section{To cite this version:}

Gabriel Galvez-Behar. The Patent System during the French Industrial Revolution: Institutional Change and Economic Effects. Jahrbuch für Wirtschaftsgeschichte / Economic History Yearbook, 2019, Patent Law and Innovation in Europe during the Industrial Revolution, 60 (1), pp.31-56. 10.1515/jbwg-2019-0003 . halshs-00544730v2

\section{HAL Id: halshs-00544730 \\ https://shs.hal.science/halshs-00544730v2}

Submitted on 13 Jun 2019

HAL is a multi-disciplinary open access archive for the deposit and dissemination of scientific research documents, whether they are published or not. The documents may come from teaching and research institutions in France or abroad, or from public or private research centers.
L'archive ouverte pluridisciplinaire HAL, est destinée au dépôt et à la diffusion de documents scientifiques de niveau recherche, publiés ou non, émanant des établissements d'enseignement et de recherche français ou étrangers, des laboratoires publics ou privés. 


\title{
The Patent System during the French Industrial Revolution: institutional change and economic effects
}

\author{
Gabriel Galvez-Behar \\ Université de Lille - Institut de recherches historiques du Septentrion \\ Preprint Version
}

\begin{abstract}
For quotation, please refer to Gabriel Galvez-Behar, "The Patent System during the French Industrial Revolution: Institutional Change and Economic Effects", Jahrbuch für Wirtschaftsgeschichte, special issue "Patent Law and Innovation in Europe during the Industrial Revolution", edited by A. Donges and F. Selgert, vol. 60, n 1, 2019, p. 31-56. [https://doi.org/10.1515/jbwg-2019-0003]
\end{abstract}

\section{Introduction}

The role of institutions in economic development is a sharply debated issue and the one played by intellectual property is particularly discussed. The time is long gone when Max Weber could claim without real discussion that "without the stimulus of [the] patent law the inventions crucial for the development of capitalism in the field of textile industry in the 18th century would nout have been possible"1 . Not only have patents been the subject of recurring controversies throughout their history, but they have also been a source of perplexity for historians and economists alike. Fritz Machlup already stated in 1958 that "if we did not have a patent system, it would be irresponsible, on the basis of our present knowledge of its economic consequences, to recommend instituting one. But since we have had a patent system for a long time, it would be irresponsible, on the basis of our present knowledge, to recommend abolishing it" ${ }^{2}$. In a sense, this kind of debate continues today in the light of new

$1 \quad$ M. Weber, General Economic History, Glencoe, Ill. :1950

2 F. Machlup, An Economic Review of the Patent System, Washington 1958 
work on patent-free innovation in the wake of what Robert Allen put forward in his 1983 seminal paper ${ }^{3}$. The discussion was revived about Great Britain, which Weber had wrongly made the cradle of the first modern patent law ${ }^{4}$. In short, even academically, the role of patent systems in economic history remains a highly controversial subject.

In fact, it is quite possible that such a question may not have an unambiguous answer. Despite their family resemblance, patent laws have strong national specificities that international regulatory institutions do not erase ${ }^{5}$. In addition, these systems experience a number of often exogenous "shocks" that can have an impact on their own implementation". Finally, one of the paradoxes of patent systems is that, for a long time, they have constituted a common base of rules for completely different industries, even if certain specificities may have been developed in some countries and for certain activities. All this requires a fairly precise look at the different regimes covered by a patent system before making comparisons and drawing lessons from them too quickly.

France was one of the first major industrialized countries to adopt a legislation on patents in 1791. It played a leading role in the emergence of the first international regulations such as the International Union for the Protection of Industrial Property (Union de Paris) in 1883. However, his role is relatively little discussed. In her book The Democratization of Invention (2005), B. Zorina Khan defended a sharp point of view about the French and British patent systems $^{7}$. By comparing Great-Britain, France and the United States, she suggested that American economic performance was based on a democratization of invention, which was

3 R. C. Allen, Collective invention, in: Journal of Economic Behavior \& Organization 4/1, 1983, pp. 1-24 ; A. Nuvolari, Collective invention during the British Industrial Revolution: the case of the Cornish pumping engine, in: Cambridge Journal of Economics 28/3, 2004, pp. 347-363 ; L. Hilaire-Pérez/C. MacLeod/A. Nuvolari, Innovation Without Patents, in: Revue économique 64/1, 2013, p. 5-8.

4 C. MacLeod, Inventing the Industrial Revolution : the English patent system, 1660-1800, Cambridge 2002 ; C. MacLeod, Patents for invention: setting the stage for the British industrial revolution?, in: Empiria. Revista de Metodología de las Ciencias Sociales 18, 2009, pp. 37-58 ; S. Bottomley, The British Patent System during the Industrial Revolution 1700-1852: From Privilege to Property, Cambridge 2014 ; S. Bottomley, Did the British Patent System Retard the Industrial Revolution?, in: The Criterion Journal on Innovation 1, 2016, pp. 65-83.

5 J. Lerner, 150 years of patent protection, in: The American Economic Review 92/2, 2002, pp. $221-225$.

6 C. Diebolt et K. Pellier, 400 ans de protection par les brevets, 400 years of patent protection: a comparative cliometric contribution, in: Revue économique 63/3, 2012, p. 611-621

7 B. Z. Khan, The Democratization of Invention: Patents and Copyrights in American Economic Development, 1790-1920, Cambridge 2005. 
allowed by its own patent system. Contrary to the American one, the "philosophy and enforcement of intellectual property in Britain and in France, the structure of patent and copyright systems, and the resulting patterns of invention, were all consistent with the oligarchic nature of European society" ${ }^{\prime}$. For her, the revolutionary rupture had only a rhetoric meaning. French mercantilist policies remained during the $19^{\text {th }}$ century: mistrust toward foreign inventions, strong involvement "in the discretionary promotion of invention" and preference for secret remained the essential features of French patterns of invention and conduced to promote rent-seeking activities, which were unfavorable to competitiveness.

Such an assessment seems all the more severe as the French patent laws has long been perceived as a system based on natural right. The purpose of this article is to revisit this contradiction in light of new sources and works ${ }^{9}$. Thanks to the historical database provided by the French Patent Office (Institut national de la propriété industrielle) and to new dissertations, it is possible to give a more comprehensive analysis of the French patent system in the first half of the 19th century. In a first part, we describe the legal framework and show its contradictory aspects: a natural right inspiration, symbolized by the so-called refusal of any preliminary examination, on the one hand ; a restrictive access due to the cost of the patent, on the other hand. Then, in a second part, we describe the implementation of the system by insisting on its different use by industries. Finally we highlights the effect of the 1844 Patent Act and suggest that the failure of the system was the result of a lack of institutional infrastructure.

\section{Inventing the French Patent System}

Admittedly, many of the problems relating to the inventors' rights appeared long before the French Revolution. The royal declaration on privileges for inventors in 1762 expressed a new

8 B. Zorina Khan, The Democratization, p. 6.

9 G. Galvez-Behar, La République des inventeurs. Propriété et organisation de l’innovation en France (1791-1922), Rennes 2008 ; J. Baudry, Une histoire de la propriété intellectuelle: les brevets d'invention en France, 1791-1844 (PhD EHESS Paris, 2014) ; C. Koblentz, La Société d'encouragement pour l'industrie nationale et les inventeurs 1824-1844 (PhD EHESS Paris, 2016). I thank the INPI and especially Steeve Gallizia and Valérie Marchal for having helped me in this research, which has been conducted as part of a collaboration between the INPI and the IRHIS. 
conception of privileges, which depended on the strong debates about the economic regulation ${ }^{10}$. In the 1780 s, even though the exclusive privilege was the subject of considerable criticism, many agreed that transitional monopolies could be granted to inventors. Inspired by the British example, the French royal administration facilitated the issuance of privileges in inventions, while easing procedures of prior expertise. In return, it required the deposit of their inventions by patentees in order to promote the development of the industrial knowledge. Recognition of the natural right of inventor, the issuance of temporary privileges as a reward for inventors and the disclosure of inventions were the three features of a model, which had appeared at the end of the Ancien Régime.

\section{The Revolution of inventors (1791)}

Despite some continuities the disruptive impact of the Revolution cannot be underestimated. The first revolutionary patent laws resulted from a strong lobbying of inventors' societies. Such organizations had come to light at the end of the Ancien Régime and in the very first years of the Revolution a new one was created: the Sociéte des inventions et des découvertes which presented a petition to the Assembly in September 1790 in order to obtain the adoption of a French patent law similar to the English one ${ }^{11}$. The representative chevalier Stanislas de Boufflers was then in charge of the issue and presented his report on 30 December $1790^{12}$. Inspired by the Enlightened philosophy, his Rapport sur la propriété des auteurs de nouvelles découvertes et inventions en tout genre d'industrie (Report on property of authors of new discoveries and inventions in any kind of industry), viewed inventions as inventor's products, which property was secured by natural rights ${ }^{13}$. At the same time, Boufflers defended also a legal system based on a clear contract between inventors and society. The society could protect his rights, but this protection had a heavy cost because of the

10 L. Hilaire-Pérez, L'invention technique au siècle des Lumières, Paris 2000.

11 C. Demeulenaere-Douyère, Défendre les intérêts moraux et économiques des inventeurs : des formes d'action collective sous la Révolution (1790-1798), in: ARTEFACT 1, 2015, pp. 165-176 ;

C. Demeulenaere-Douyère, Inventeurs en Révolution : la Société des inventions et découvertes, in: Documents pour l'histoire des techniques 17, 2009, pp. 19-45

12 N. Vaget Grangeat, Le chevalier de Boufflers et son temps. Étude d’un échec, Paris 1976.

13 S. de Boufflers, Rapport sur la propriété des auteurs de nouvelles découvertes et inventions en tout genre d'industrie, Paris 1791. 
immaterial nature of invention. In order to compensate it, the inventor had not only to give up his secret by providing an exact knowledge of his invention, a sine qua non condition for effective protection, but he had also to renounce his rights after a particular time span.

Although temporary, this protection was still the manifestation of a natural right philosophy. Preliminary examination by the administration had no legitimacy. Whether conducted by scholars of the Académie des sciences or by members of corporations, such an examination was, in Boufflers' eyes, necessarily arbitrary because it established "a court judging for things that do not yet exist." ${ }^{14}$ For him the administration was unable to take a decision on the usefulness of new things, which could only be judged by the public opinion. On January $7^{\mathrm{d}} 1791$, Boufflers' bill became the first patent law in France but it was immediately contested by those, who considered that patents were useless privileges. Thanks to a new strong lobbying effort, a second patent law, confirming the first one, was adopted and promulgated on May $25^{\text {th }} 1791$. In order to draw a strict distinction from the old privileges, itcalled the patents "brevets d'invention" and drew the new patent administration. This rejection of any State intervention in the granting of patents was a real rupture.

Besides, the 1791 patents laws established three sorts of patents :

— Patents for invention, which protected "every discovery or new invention"15 ;

— Patents for improvement, which protected "every way to bring every kind of production to a new kind of perfection"16 ;

— Patents for importation, which protected "anyone who [would bring] first in France a foreign discovery" $" 17$.

In practice, hybrid categories were used and some patents were labeled as ones "for invention, improvement and importation"

14 Archives parlementaires, I/21, Paris 1885, p. 734 (30 December 1790).

15 G. Emptoz/V. Marchal, Aux sources de la propriété industrielle: guide des archives de l’INPI, Paris 2002.

16 Id.

17 Id

18 This issue has some methodological implications. In our analysis, we have considered these "mixed" patents out of our samples in order to avoid any confusion. 
Patents were granted for 5, 10 or 15 years. Although they were considered a human right, they were far from being accessible due to their very prohibitive cost. The patent tax was indeed very expensive: for a 5 years it raised 300 francs, for 10 years to 800 francs, for 15 years to 1500 francs. Even though only the half of the cost had to be paid immediately by requesting the patent - and the rest six months later - other taxes had to be added. Compared to the 1,5 francs a day worker's average wage, this tax made the French patents inaccessible to many inventors. While patents were supposed to constitute a natural right, their grant was a real obstacle to such recognition.

\section{Reform attempts (1791-1844)}

As we see, the French patent laws were immediately subject of sharp criticism, which explains that some modifications were quickly introduced. An act of September $20^{\text {th }} 1792$ prevented from patenting financial methods. But more radical projects also appeared in order to undermine the compromise imposed in 1791. On 14 Pluviôse an VI (February $3^{\mathrm{d}}$ 1796), a report to the Conseil des Cinq-Cents suggested that patents should be issued only after a "mature consideration"19. This apparent challenge to the principle of non preliminary examination caused, in turn, so strong reactions, that the project had to be abandoned. In 1811 the Conseil général des fabriques et des manufactures intended to reform the patent laws but its work remained unsuccessful. In 1814, the issue was raised again, without further success. Three years later, the same commission addressed the issue again and again things were dragging on until the Minister of Trade revived the project in $1826^{20}$. Patents becoming more and more important, the Minister of Trade, the Comte de Saint-Cricq convened in October 1828 a commission to prepare a new patent law.

Because of the complexity of the problem, the commission undertook a wide consultation, whose results reflected the different uses of the patent ${ }^{21}$. Rare were those who, like the Société

19 A. Huard, Répertoire de législation et de jurisprudence en matière de brevets d'invention, Paris 1863, p. 13.

20 Archives nationales, Pierrefitte-sur-Seine (thereafter AN), F12 196 bis: Meetings of November 18, 1824, 20 October 1825 and April 6, 1826.

21 Recueil industriel, manufacturier, agricole et commercial 39, 1830, pp. 119-153/209-236, 40, 1830, pp. 2850. 
des arts et des sciences of Lille, called for the abolition of patents in favor of a system of rewards. Instead, most considered the patent as the best way to give special rights to inventors. On many other points, however, opinions were much more divergent. The preliminary examination, claimed by chambers of commerce of Boulogne, Montpellier and Tours, was rejected by those of Lyons, Marseille and Paris.

The reform of the patent legislation took along time because political turmoil took precedence over economic discussions. Under the Monarchie de Juillet a new reform was planned once more : in 1832, the Minister of Trade established again the commission created in 1828 and added the famous chemist Gay-Lussac and two other members. A year later, the commission adopted a report which was presented to the Conseil général de l'agriculture, $d u$ commerce et des manufactures only in 1837. Six more years were necessary to have a comprehensive reform. In 1838, an Act on the justice of peace removed the examination of the validity of patents by simple magistrates. Patents cases had to be judged by civil or criminal courts. A bill was presented in 1843 to the Parliament. More than a year of debates was still required to have the new law, which was promulgated on July 5, 1844. This new French patent law would govern the patent system until 1968.

\section{The 1844 patent law: a new deal ?}

The 1844 patent law was adopted in a particular context. The late 1830 s and early 1840 s were a moment of industrial crisis in Europe ${ }^{22}$. In France, for instance, the linen industry was seriously challenged by British competitors. The development of railways faced shortcomings of domestic metal supply. Some initiatives were taken to improve the situation. In 1839 and 1844, two national exhibitions of industrial products showed how the French industry was active. Protectionist movements arose ${ }^{23}$. Because of the final removal of export controls of British machines in 1843, the French machine-making industry demanded new kinds of legal

22 M. Lévy-Leboyer, Les Banques européennes et Findustrialisation internationale dans la première moitié du XIXe siècle, Paris 1964.

23 D. Todd, L’identité économique de la France. Libre-échange et protectionnisme, 1814-1851, Paris 2008. 
protection. The economic crisis promoted an institutional change in order to protect the French national industry.

The French patent reform echoed on such a context. Contrary to the 1791 acts, the 1844 Act did not include any preamble to define its philosophical principles. This weakening of the principle of invention's ownership was justified by the benefit of a contractual basis, already outlined by Boufflers but not in the same terms. This conception was not unanimously accepted and many people continued to defend another one based on natural right considerations. However, if the law no longer considered the inventors' right as a property one, it continued to be based on the refusal to see the government delivering a privilege : the spirit of revolutionary laws and its natural right foundations seemed at last to be preserved.

The main change consisted in a narrower definition of invention. Whereas the 1791 patent acts were vague on this issue, article 2 of the 1844 Act defined patentable "inventions or discoveries" by distinguishing three cases: the invention of new industrial products, the invention of new ways, the new application of known methods to produce a result or an industrial product. Thus, the new law did not consider the importance of the invention, which had only to meet two conditions: to be new and to have an industrial character. A method of cultivation or a method of reading were not considered industrial, and they could not, therefore, be patented. The law also provided criteria excluding purely theoretical discoveries. Besides, financial combinations and pharmaceutical products were removed from patentability.

One of the most important change dealt with the patents for importation and with the status of foreign people. Patents for importation had been subject of fierce criticism because they enabled people who were not inventors nor industrialists to take out a patent only by importing an invention from foreign countries to France. The 1844 law abolished patents for importation but authorized foreigners to take out patents in France under the same conditions as the French citizens. In addition, it removed the provision of the 1791 Act, which enabled the invalidation of the patent of a person exporting his invention. The new patent law was part 
of a new context where France was no longer only an importer but also an exporter of industrial products. However, the 1844 reform aimed also to protect the French industry. It provided that persons patented abroad may only obtain patents in France that would be valid until the end of their foreign ones. Finally, the obligation to exploit French patents in France and the prohibition made to import from abroad objects patented in France give to the 1844 law a protectionist character.

Another important issue concerned the cost of patents. The total cost of 5 and 10 years patents was increased, respectively up to 500 and 1000 francs. But the new act allowed patentees to spread the payment of the tax over all the duration of their patent. In practice, patent costed 100 francs each year whereas workers' wage represented about 1,5 francs a day at mid-19th century. Although modest workers could not have yet real access to patent, this effective fall of price allowed artisans or small entrepreneurs to use the patent system.

From a philosophical point of view, it appears clearly that the French patent system was based on natural right and this conception appeared democratic since every inventor had the right to have his invention protected by the law. Obviously, the cost of patent limited in practice this ideal but the patent legislation was based on new foundations. By decreasing the actual cost of patent, the 1844 patent Act promoted a democratization of patenting, which accelerated the increase of the number of granted patents, which had already started in the late 1830s. However, despite this new development, the French patent system did not work better.

\section{A fragmented patent system}

Analysis of the legal framework already shows that, far from being static, the French patent system evolved in the first half of the 19th century. A better understanding of its economic impact needs however to see how this legislation was implemented. In this section, we look at the diffusion of patents in time and space and at the types of industries involved and at the litigation. 
The adoption of the French patent laws in 1791 did not cause any upheaval in the delivering of patents although they sanctioned a breach in the legal system. On the contrary, in a first instance, granted patents were as numerous as applications for privileges at the end of Ancien Régime. In the 1780s 16 applications had been filed on average each year to the Comité du commerce. Between 1791 and 1801, 15 patents were delivered on average each year. The number of patents continued to stagnate until the reign of Charles X (1824-1830), when it begun to rise rapidly. After the 1830 Revolution and Louis-Philippe's advent, this increase accelerated significantly before the 1844 reform: the 1838 Justice of Peace Act and the 1839 industrial exhibition played probably a role in this process. Then, the 1844 patent act accelerated the dynamics. Between the early 1840s and the late $1850 \mathrm{~s}$, the number of granted patents was multiplied by three. Then, from the late 1850 s until the 1870 s, the number of granted patents remained stable, probably because the important controversies which challenges the patents laws in France and in Europe.

\section{Insert Chart 1.}

\section{The patents' territories}

Another aspect is the geographical diffusion of the patents. The geographical distribution of patents by city of patentees shows a very high concentration in Paris. Such a phenomenon can be explained by the fact that Paris was one of the major French industrial areas but also because controlling any infringement was easier in this area ${ }^{24}$. Another complementary explanation is the proximity of the patent administration, whose office was the only place to give real access to the patents in force. Furthermore, it was common for the provincial patentees to give the Parisian address of their patent agent. Anyway, the relative scarcity of patents in Province is confirmed in such an industrial area as Northern France ${ }^{25}$. According to Jean-Pierre Hirsch, "not only the share of patents granted in this Mecca of the industrialization of the nineteenth century [did not reach] even $3 \%$ corresponding to the

$24 \quad$ J. Baudry, Histoire, pp. 78-79.

25 J.-P. Hirsch, À propos des brevets d'invention dans les entreprises du Nord au XIX ${ }^{\mathrm{e}}$ siècle, in: Revue du Nord 67/265, 1985, pp. 447 -459. 
relative importance of its people," but the number of patents relating to the northerner textile industry, industrie-phare in this French department, was ridiculously low. Nevertheless, other departments in the Province had a stronger presence of patentees than average: they were dominated by cities such as Lyons, Marseille, Bordeaux or Rouen.

\section{Insert Chart. 2.}

The geography of the French patent system was not limited to France however. If we consider the patentee's origin, London had the second rank. Before 1839 , about $80 \%$ of the patents granted to London citizens were patents for importation. Reversely these latter represented about $10 \%$ all patents granted from 1791 and 1839 and about $80 \%$ of patents for importation were taken out by London citizens. The patents for importation were a way to allow British patentees or industrialist to diffuse their technology in France by providing a monopoly. In the early 1840 s more than $50 \%$ of the patentees came from Paris and London kept its second rank. The 1844 reform did not really change this order: the position of Paris became stronger (from 53\% to 55\% in 1845-1847) although the weight of London receded a little (from 5,03\% to 3\%). The new patent law did not really upset the geographical structure of patentees.

Insert Table 1

\section{Diversity in patenting profiles}

The distribution of the number of patents by type of industry provides a better understanding of the role played by the patent system and a better measure of the influence of the 1844 reform (see Appendix 1). If this distribution depends on the classification made a posteriori by the French patent office, its analysis reveals however several phenomena. First of all, throughout the period and even after 1844, three industries dominated this distribution: the textile industry, the mechanical industry and the chemical one. All three are at the heart of the technical system of the first industrial revolution and are characterized by a relatively strong capital intensity. Then three industries saw the development of patents until the 1830s: the 
building industry, the heating and lighting industry, two fields linked to urbanization, and the mechanical industry. On the other hand, some sectors remained rather scarce such as the articles de Paris (fashion products), office material but also the railways industry. Of course, this distribution was not static. From 1791 to the late 1830s, patents to textile and chemical industries stepped back whereas other sectors became more present, especially the mechanical industry. Although it is difficult to make the connection from a statistical point of view, it seems that the patent system depended on investment cycles in these different spheres of activity.

The patent for importation did not represent a great share of all the granted patents. If we do not consider the mixed patents, they were about $10 \%$ of the total amount. It does not mean that foreign inventors were so rare since they could also take out some patents for invention. Furthermore, protecting domestic inventions and importing foreign ones was not contradictory. The industries that used patents for inventions the most were also those that used patents for importation the most and conversely. In this case also, heterogeneity was a key issue. Until the 1830 s, patents for importation were over-represented in the textile, mechanical and shipbuilding industries. But agriculture, office material or articles de Paris industry did not give rise to a lot of patents for importation. The French patent system thus seems to have been first solicited by rather capital-intensive industries at the heart of technological exchanges, especially with Great Britain.

However, this description has to take into account the duration of the patents. Because of cost consideration, it can be viewed as a clue of their importance from the patentee's point of view. Between 1791 and 1844, patents could be voided if the second part of the total amount of the tax had not been paid. More than $20 \%$ of patents belonged to that category (about $26 \%$ between 1831 and 1843) ${ }^{26}$. Moreover, nearly half of the patents were granted for a 5-years term, probably because of their relatively lower cost.

Insert Table 2.

26 J. Baudry, Histoire, p. 139. 
Although patents delivered for a 10 years term increased significantly in the 1820 s, the duration remained almost stable. However, patents for importation were taken out for a more long time. Besides, the duration depended also on the type of industry. Actually, patents were shorter in industries where they were rare. Capitalistic industries such as railways, mining or chemical industries were characterized by longer patents.

\section{Insert Chart 3.}

Like its legal definition, the actual French patent system appeared to be full of contradictions in the first half of the $19^{\text {th }}$ century. Patents were primarily used by a small number of capital-intensive industries at the heart of the industrialization process. Their geographical distribution was fundamentally unequal and almost caricaturally opposed Paris and the province. Finally, patents also differed in their duration, longer for those related to key-industries and shorter for others. In fact, the French patent system appeared quite dual. The question then is whether the 1844 reform unified it or, on the contrary, increased its fragmentation.

\section{The effects of the 1844 reform}

The 1844 reform was preceded by an increase in the number of patents from the late 1830s. This increase coincided with the discussion and adoption of the Justice of Peace Act in 1838. By shifting patent cases from simple magistrates to civil and correctional courts, the 1838 Act significantly strengthened the legal security of the patent system. More reliable, the latter became more attractive. The 1844 reform was part of this dynamic but neither the 1838 nor the 1844 acts brought structural upheavals. Although the quantitative growth in the number of patents is real, the geography of the system remains stable overall. As for the breakdown by industry, it is certainly characterized by a decline in the textile industry and an increase in patents in the mechanical industry, but these developments are explained by cyclical circumstances. In 1850, the distribution by industry was fairly close to that of the late 1830 s. Finally, the occupational distribution of patentees remains fairly stable. Even if the number of 
patentees declaring themselves "mechanics" increased significantly after the 1844 reform, the weight of manufacturers, manufacturers and traders remained predominant.

The most notable change is in the duration of patents. After 1844, paradoxically, the annual payment made this duration shorter. According to the Chamber of Commerce of Lille, the annual tax could be now afforded by no-wealthy inventors ${ }^{27}$. Only $55 \%$ of the patents granted in 1844 and 1845 were still in force after one year and only $16 \%$ had a duration for more than 5 years $^{28}$. This phenomenon remained stable in the next decades and suggests that the 1844 reform boosted first short life patents, which were likely junk ones.

Such an assumption is confirmed by the evolution of another practice. The preliminary examination of patents had been rejected in 1791 to avoid any censorship of the industry, which remembered the Ancien régime way in the granting of privileges. Nevertheless, as shown by Jean-Pierre Hirsch and Jérôme Baudry, an unofficial but very real examination was set up and implemented by the Comité consultatif des Arts et des Manufactures ${ }^{29}$. The latter could give a positive or negative opinion on the merits of patent applications, even though this opinion was not be fully binding. It seems however that after the adoption of the new patent law in 1844 , the Comité stopped playing such a role, excepted in particular cases $^{30}$. From 1844 , the patents were delivered without any governmental guarantee and even without any governmental serious regard. Only the civil or criminal courts, whose role had been reinforced six years sooner, had to judge the relevance of patents, whose quality before trial remained uncertain. The 1844 patent reform enabled a kind of democratization of patents by lowering their price and by respecting the principle of non-governmental commitment in their granting.

27 Archives départementales du Nord (now ADN), 76 J 1792, August 1855.

28 L. Nouguier, Des brevets d'invention et de la contrefaçon, Paris 1856, p. 536.

29 J.-P. Hirsch, À propos des brevets, ; J.-P. Hirsch/P. Minard, "Laissez-nous faire et protégez-vous beaucoup” : pour une histoire des pratiques institutionnelles dans l'industrie française (XVIII ${ }^{\mathrm{e}}$-XIX ${ }^{\mathrm{e}}$ siècle)' in L. Bergeron/P. Bourdelais (Ed.), La France n'est-elle pas douée pour l'industrie?, Paris 1998, pp. 135-158 ; J. Baudry, L'échec et les brevets d'invention (France, 1791-1844), in: N. Coquery/M. de Oliveira (Ed.), L’échec a-t-il des vertus économiques ? : Congrès de l'Association française d'histoire économique des 4 et 5 octobre 2013, Vincennes 2016, pp. 47-56 ; J. Baudry, Examining inventions, shaping property: The savants and the French patent system, in: History of Science, 2018, https://doiorg.inshs.bib.cnrs.fr/10.1177/0073275318767233.

30 J.-P. Hirsch/P. Minard, “Laissez-nous faire”, p. 156. 


\section{New shortcomings}

This statement is corroborated by the contemporaries' impression of a proliferation of ephemeral patents and of litigation. In the first years of application of the 1844 Patent Act, the number of cases brought before civil or criminal courts was increasing quite quickly ${ }^{31}$. Anyway, these figures show a sharp increase in litigation between 1846 and 1858, which is obviously to compare with that of patents themselves. However, whether civil or correctional court, if we compare the number of cases decided in the first instance to the number of patents that might be in force, the rate tended to drop from 1845 to 1866 and stabilised after. Four years later, the General Director of Agriculture and Commerce said in turn that" under the new law, it has not seen a decline in the number of trials in which the patents give rise constantly, they have rather increased ${ }^{32}$. This situation was all the more sensitive that court decisions were often contradictory and then contested. In 1850, the Minister of Commerce had recognized the inconsistency of court decisions since "such a patent, valid in a jurisdiction court, is void in the neighbor one ; such an act is qualified as counterfeiting in Paris and elsewhere this same act escapes any repression."33. Six years later, faced with these problems and limited powers of judges in the technical matter, Charles Laboulaye claimed, unsuccessfully, the introduction of "industrial consular courts" elected in the manner of commercial courts and charged with judging the trials relating to patents ${ }^{34}$.

This contradiction dealt also with an important issue: the diffusion of technical knowledge. Access to granted patents, by viewing or by publishing them, was even more essential that, in the French patent system, the application was now under the sole responsibility of the inventor. Besides, the accuracy of the technical knowledge included in patents was necessary

31 We must take great care with statistics from the Compte général de l'administration de la justice civile et commerciale failing to learn more about their construction; those in the criminal justice system are more secure due to the relatively strict correctional courts in matters of counterfacting. P. Jobert, Leçon des chiffres : le compte général de l'administration de la justice civile et commerciale au XIXe siècle, in $M$. Merger /D. Barjot (Ed.), Les entreprises et leurs réseaux : hommes, capitaux, techniques et pouvoirs. Mélanges en l'honneur de François Caron, Paris 1998, p. 67-83.

32 L. Nouguier, Des brevets d'invention, p. 531.

33 ADN, 76 J b17d66.

34 Bulletin de la Société d'encouragement pour l’industrie nationale II/3, 1856, p. 264. 
to ensure their validity and to fulfill their social function, which fitted with the spirit of “industrial Enlightenment” 35 . On a pragmatic level, however, things were less obvious.

In fact, the revolutionary French patent laws had provided the publication of patents which were felt into the public domain. But only the decree of 17 vendémiaire VII (October 8, 1798) committed really this task to the Conservatoire des arts et métiers ${ }^{36}$. Therefore, the expired patents were studied by pupils of the school of drawing and descriptive geometry established at the Conservatoire ${ }^{37}$. Clearly, this use of the patents was at the core of a technological discourse, which emerged from the late $18^{\text {th }}$ century ${ }^{38}$. The place of patents in the main technical literature from the early $19^{\text {th }}$ century may convince of that central role. However, access to patents in force was more complex. To allow the searches for antecedence, the 1791 patent laws made every citizen able to "consult the specifications of the various patents currently in office" (article 11). This possibility, however, was subject to a number of criticisms: in 1811, a commission established by the Conseil général des arts et manufactures claimed that patent descriptions were disclosed only on an Minister's order, who could refuse consultation depending on the circumstances ${ }^{39}$. In fact, this request reflected a certain distrust of inventors who did not accept to have their inventions known by the public, although they wanted to claim ownership on them. In total, even though the publication of expired patents was clearly encouraged, concrete access to patents in force did not seem too convenient, even if some owners did not hesitate to publish their inventions in technical reviews. In the province, the situation could be worse.

Even if it allowed an access and a publishing of patents, the 1844 patent act did not really improve the situation. In fact, the government refused to effectively assume this task, which was essential for the proper functioning of liberal compromise. Having efficient access to delivered patents was a necessary condition in order to make the patent system work, since it

35 J. Mokyr, The Gifts of Athena. Historical Origins of the Knowledge Economy, Princeton 2002.

36 P. Molard, Description des machines et des procédés, Paris 1811, p. 111

37 Ibid., p. 4. On this school, see A. Mercier, Les débuts de la“ petite école ". Un apprentissage graphique au Conservatoire sous l'Empire, in: Cahiers de l'histoire du CNAM 4, 1994, pp. 27-56.

38 J. Mertens, Technology as the science of the industrial arts : Louis-Sébastien Lenormand (1757-1837) and the popularization of technology, in: History and Technology18/3, 2002, pp. 203-231.

39 AN, F12 194, 27 May 1811. 
was founded on an non-examination of applications. But the publishing of patents did not fulfil the expectancies. In 1859, Charles Laboulaye denounced the shortcomings of the publication of patents:

\begin{abstract}
"At long intervals, two or three years after the time the patent could be issued, when the novelty that had been searched no longer exists, is published a large volume in- $4^{\circ}$, with a high price, containing a multitude of patents more or less truncated, without any order and all sorts of topics. Anyone interested in one or two questions, which might have some interest to see five or six patents, is careful not to lose valuable time leafing through these volumes, avoid buying them, and this costly publication is, in reality, done almost in vain" 40
\end{abstract}

Six years later, the Minister of Trade recognized "that the publication of patents could not be done with the desired speed, because of the lack of resources available to administration, [which] caused the delays" ${ }^{\prime 1}$. Nonetheless, criticisms and proposals to the Government remained unsuccessful. These shortcomings sounded like an admission of failure for the government, which was unable to make the patent system efficient, in spite - or because of its liberal ideology.

\title{
New controversies and unsuccessful reforms
}

Far from shutting down critics, the 1844 Patent Act fueled a controversy which appeared in the second half of 1840s and was increasing with the emergence in Europe of new patent laws $^{42}$. In 1852, Britain expanded its patent legislation, by reducing the burden of taxes, reinforcing the patent publicity and establishing a sort of examination ${ }^{43}$. In 1854 , the new Belgian law, which defined a patent period for twenty years and established inexpensive and progressive annuities, caused in France a strong debate and called to the fore one of its ardent actors, Ambroise Marcelin Jobard, director of the industrial Museum of Brussels. Supporter of a perpetual property for the inventor, Jobard was since the mid 1840s in the core of a

40 C. Laboulaye, Brevets d’invention, in: Bulletin de la Société d'encouragement pour l'industrie nationale II/6, 1859, p. 22.

41 Annales du Sénat et du Corps législatif 5, Paris 1865, p. 238 (27 May 1865).

42 F. Machlup/E. Penrose, The Patent Controversy in the Nineteenth Century, in: The Journal of Economic History 10/1, 1950, pp. 1-29.

43 H. Dutton, The Patent System and Inventive Activity During the Industrial Revolution 1750-1852, Manchester 1984 ; S. Bottomley, The British Patent System during the Industrial Revolution 1700-1852: From Privilege to Property, Cambridge 2014. 
powerful polemic against Joseph Garnier, the guardian of French liberal political economics temple. Jobard's success, which was demonstrated by the adoption of the new Belgian law, encouraged more French lawyers to pronounce in favour of patent's perpetuity.

Published in the Journal des débats on August 19, 1854, an article revived a major controversy which was illustrated by the disagreements among French liberal economists about the patent system. Thus the main ancestor of liberal economists, Jean-Baptiste Say, supported the patents because of their positive influence in the development of English industry. For Say, patents were a legitimate reward for the inventor ${ }^{44}$. As Say's spiritual heir and as the founder of the French Association for free-trade, Joseph Garnier took a similar position, without really settling the arguments that had emerged since Say's death ${ }^{45}$. Another figure of the liberal economics, Gustave de Molinari, adopted nevertheless a clearer position by advocating inventor's right which would be guaranteed in its natural limits ${ }^{46}$. By contrast, the young Frederic Passy expressed clearly against patents ${ }^{47}$. In short, on the issue of industrial property, the French liberal school was far from being unanimous and the divisions caused by this issue were not confined to a clash between free trade and protectionism.

In fact, beyond these individual differences, there were such antinomies which manifested different conceptions of invention. Indeed, from similar values, like a work-based conception of property or the freedom of trade and labor, free trade economists reached different conclusions. Considering the invention as the fruit of an individual work conduced to recognize an inventor's property right. Refusing such a recognition violates the freedom to work and meant a sort of return to corporations. In this case, patents had to be abolished. For others' invention was foremost collective (that was the idea put forward by Passy), each invention being more dependent on the social development than on individual efforts. But was not such a logic a way to socialism? In short, these economists were faced with the

44 J.-B. Say, Traité d'économie politique, ou Simple exposition de la manière dont se forment, se distribuent et se consomment les richesses, Paris 1803, p. 265.

45 J. Garnier, Traité d'économie politique, sociale ou industrielle, Paris 1873, p. 701-705.

46 G. de Molinari,De la propriété des inventions, in: Journal des économistes, 15 septembre 1855, p. 410430.

47 F. Passy, Question des brevets. Des objections que soulève la théorie du monautopole, in: Journal des économistes, 15 novembre 1854, p. 258-275. 
impossibility to establish firmly intellectual property rights and did not succeed to give definitive solution to the issues raised by the patent.

All these critics made necessary a reform of the patent law. In 1857, a project was discussed by the Conseil d'État but it was impossible to find a unanimous consent. Therefore, after the universal exhibition in 1862, the famous economist Michel Chevalier launched an offensive against the patent system : for him inventive was first of all collective and appropriation of invention had no sense. Consequently, the reform project was forgotten, but, even if it was threatened, the French patent system did not disappear.

Five years later, in the introduction of his famous treatise on industrial property, the lawyer Eugène Pouillet added :

\begin{abstract}
"Delete patents, replace the same even by a system of rewards whatsoever, do you not see that the large manufacturer, being able once to enjoy the invention, will took it as quickly as possible, and playing his ordinary game, will crush his competitors ? [...] Where will be indeed the interest of these great lords to do better? They will be alone, and consumption willy-nilly be forced to take their products, since there will be no other. We will come back as a state of affairs even worse than the masters and guilds, and we will just have moved from an evil excess to another. Let those who call themselves democrats, who call themselves friends of the people, and at the same time calling for the abolition of patents, open their eyes. “48
\end{abstract}

Far from being a vestige of the privilege mentality, the French patent law was seen as a democratic promise.

\title{
Conclusion
}

This brief description of the French patent system in the first half of the 19th century reveals all its contradictions. Originally, it was supposed to ensure recognition of the inventor's natural right by rejecting any preliminary examination that could recall the practices of the Ancien Régime. However, the prohibitive cost of patenting and the unofficial preliminary examination restricted access to the patent. The French system was then used mainly by a small number of industries at the heart of the industrialisation process - textiles,

48 E. Pouillet, Traité théorique et pratique des brevets d'invention et de la contrefaçon, Paris 1872, p. XXXXI. 
chemicals, mechanics - and international trade. From a geographical point of view, it is dominated by Paris and concerns only a few provincial cities. It hardly fulfils its function of disseminating technological information and its legal reliability was criticized. The 1791 patent system seems dual and rather fragile, but its capacity to resist the attempts at abolition, which appeared very early, shows not only that ideological aspects are far from secondary but also that it meets the needs of institutions in French economic circles in that period.

The 1838 Justice of Peace Act and the 1844 Patent Act restructured the system, which adapted to the economic context. While the model derived from the 1791 acts was characterized by a difficult access (high cost and unofficial examination) and a fragile ex-post judicial regulation, the new model strengthened this latter by entrusting it to more professional courts. Furthermore, it made access to the system easier by lowering the effective cost of patents and by much more rigorously applying the principle of prior non-examination. To a certain extent, this change came close to the 1791 ideal of the inventor's natural right, but it degraded the functioning of the system by reducing the life of patents - which can be a clue of their quality - and by not reducing the absolute number of litigation. Furthermore, there was no real improvement in the disclosure of technological information. Paradoxically, the evolution of the system in a more democratic way made it more problematic. In any case, the idea of structural continuity with the practices of the Ancien Régime does not stand up to analysis despite Tocqueville's invocation.

In fact, this contradiction shows how impossible it is to evaluate the economic performance of patenting by an explanation in terms of democratization of the invention or of social dynamics of the inventive actitivy. Equally important is the consistency of institutional choices with economic expectations. The French system has long suffered from the State's reluctance to provide sufficient tools to make patents efficient. In contrast, the creation of the Patent Office in the United States and the adoption of a preliminary examination in 1836 may have played a fundamental role. The desire not to increase the place of the administration and the 
attachment to the democratic character of the patent made these two measures difficult to accept in France. 


\section{Appendix 1}

The distribution of patents by industry (1791-1839)

Classe

01. Agriculture

02. Food industry

03. Railways

04. Textile industry

05. Mechanical industry

06. Navy \& sailing

07. Building

08. Mining \& metallurgical industries

09. Household Equipment

10. Road Transport

11. Weapons

12. Precision Instruments

13. Ceramic Industry

14. Chemical industry

15.Lighting - Heating -

Cooling industry

16. Clothing industry

17. Industrial Arts

18. Office Material

19.Surgery and Medicine

20. Articles de Paris

$\mathrm{N}=$

Source
Patent for invention

1

1791-1819

22

62

1820-1829

$1830-1$

218

82

27
61
1

$830-183$

9

179

230

47

236

142

397

328

36

37

52

68

68

219

37

29

30

45

50

28

41

28

134

66

112

107

65

107

59

272

213

171

156

67

146

54

2983

1276

1073

INPI Historical Database

Patent for importation 791-1819 1820-1829 1830-1839

$\begin{array}{rrr}2 & 1 & 2 \\ 3 & 11 & 20 \\ & & 6 \\ 22 & 47 & 65 \\ 12 & 19 & 48 \\ 8 & 10 & 17 \\ 4 & 3 & 16\end{array}$

$\begin{array}{rrr}5 & 7 & 16 \\ 1 & 2 & 6 \\ 6 & 10 & 4 \\ 5 & & 8 \\ 2 & 1 & 5 \\ 3 & 4 & 8 \\ 15 & 15 & 26\end{array}$

$\begin{array}{rrr}2 & 6 & 31 \\ 6 & 10 & 15 \\ 9 & 7 & 12 \\ 2 & 2 & 3 \\ 4 & 4 & 7 \\ 1 & 1 & 4 \\ 112 & 160 & 319\end{array}$


Classe

01. Agriculture

02. Food industry

03. Railways

04. Textile industry

05. Mechanical industry

06. Navy \& sailing

07. Building

08. Mining \& metallurgical industries

09. Household Equipment

10. Road Transport

11. Weapons

12. Precision Instruments

13. Ceramic Industry

14. Chemical industry

15.Lighting - Heating -

Cooling industry

16. Clothing industry

17. Industrial Arts

18. Office Material

19.Surgery and Medicine

20. Articles de Paris

$\mathrm{N}=$

Source
Patent for improvment

1791-1819

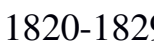

6

1830-1839

6
15

9

9
44

41

Hybrid patents

$\begin{array}{rrr} & & 45 \\ 95 & 130 & 346 \\ 21 & 61 & 237 \\ 16 & 43 & 37 \\ 10 & 48 & 126\end{array}$

6

6

5

15

10

3

8

8
64

52

52
19

69

44

24

16

20

14

707

381

INPI Historical Database
1791-1819

1820-1829 1830-1839

16

20

$32 \quad 70$

$3 \quad 19$

$117 \quad 260$

$54 \quad 130$

$24 \quad 34$

44

67

$48 \quad 21 \quad 36$

$\begin{array}{llll}50 & 3 & 21 & 58\end{array}$

$\begin{array}{llll}108 & 9 & 15 & 43\end{array}$

$\begin{array}{lll}73 & 1 & 17\end{array}$

17

16

54

63

54

51

16

26

18

669
31

45

20

114

109

79

67

33

60

31

1326 


\section{Appendix 2}

The distribution of patents by industry and by expected duration in 1850

Classe

\begin{tabular}{|c|c|c|c|c|}
\hline \multirow[b]{2}{*}{ 01. Agriculture } & 5 years & 10 years & \multicolumn{2}{|c|}{ Foreign } \\
\hline & $16,67 \%$ & $4,44 \%$ & $3,90 \%$ & $1,42 \%$ \\
\hline 02. Food industry & $5,56 \%$ & $6,67 \%$ & $5,65 \%$ & $4,96 \%$ \\
\hline 03. Railways & & & $1,35 \%$ & $4,26 \%$ \\
\hline 04. Textile industry & $22,22 \%$ & $20,00 \%$ & $11,51 \%$ & $21,99 \%$ \\
\hline 05. Mechanical industry & $5,56 \%$ & $11,11 \%$ & $12,11 \%$ & $12,06 \%$ \\
\hline 06. Navy \& sailing & & $2,22 \%$ & $2,62 \%$ & $7,09 \%$ \\
\hline 07. Building & $5,56 \%$ & & $5,11 \%$ & $3,55 \%$ \\
\hline \multicolumn{5}{|l|}{ 08. Mining \& } \\
\hline metallurgical industries & & & $2,76 \%$ & $4,96^{\circ}$ \\
\hline \multicolumn{5}{|l|}{ 09. Household } \\
\hline Equipment & $5,56 \%$ & $4,44 \%$ & $4,85 \%$ & $0,00 \%$ \\
\hline 10. Road Transport & & $4,44 \%$ & $2,49 \%$ & $2,84 \%$ \\
\hline 11. Weapons & $5,56 \%$ & $2,22 \%$ & $1,21 \%$ & $0,00 \%$ \\
\hline \multicolumn{5}{|l|}{ 12. Precision } \\
\hline Instruments & & $4,44 \%$ & $3,84 \%$ & $4,96 \%$ \\
\hline 13. Ceramic Industry & $5,56 \%$ & $4,44 \%$ & $1,88 \%$ & $4,26 \%$ \\
\hline 14. Chemical industry & $5,56 \%$ & $11,11 \%$ & $10,36 \%$ & $9,22 \%$ \\
\hline \multicolumn{5}{|l|}{ 15.Lighting - Heating - } \\
\hline Cooling industry & & $4,44 \%$ & $8,08 \%$ & $4,26 \%$ \\
\hline 16. Clothing industry & & $13,33 \%$ & $5,11 \%$ & $1,42 \%$ \\
\hline 17. Industrial Arts & $5,56 \%$ & $2,22 \%$ & $4,44 \%$ & $4,96 \%$ \\
\hline 18. Office Material & & & $2,42 \%$ & $1,42 \%$ \\
\hline \multicolumn{5}{|l|}{ 19.Surgery and } \\
\hline Medicine & $16,67 \%$ & $2,22 \%$ & $4,58 \%$ & $4,26 \%$ \\
\hline \multirow[t]{2}{*}{ 20. Articles de Paris } & & $2,22 \%$ & $5,72 \%$ & $2,13 \%$ \\
\hline & $100,00 \%$ & $100,00 \%$ & $100,00 \%$ & $100,00 \%$ \\
\hline $\mathrm{N}=$ & 18 & 45 & 1486 & 14 \\
\hline
\end{tabular}

Source : INPI Historical Database 


\section{Table 1}

Patentees' geographical origin in the 1840 s

\begin{tabular}{|c|c|c|}
\hline \multicolumn{3}{|c|}{ Origin of patentees } \\
\hline City & $1841-1843$ & $1845-1847$ \\
\hline Paris & $53,11 \%$ & $55,00 \%$ \\
\hline Londres & $5,03 \%$ & $3,23 \%$ \\
\hline Lyon & $3,51 \%$ & $3,70 \%$ \\
\hline Marseille & $1,25 \%$ & $1,94 \%$ \\
\hline Rouen & $1,52 \%$ & $1,25 \%$ \\
\hline Bordeaux & $1,46 \%$ & $1,25 \%$ \\
\hline Lille & $1,28 \%$ & $1,18 \%$ \\
\hline Nantes & $0,39 \%$ & $0,83 \%$ \\
\hline Bruxelles & $0,56 \%$ & $0,69 \%$ \\
\hline Roubaix & $0,65 \%$ & $0,61 \%$ \\
\hline Strasbourg & $0,24 \%$ & $0,80 \%$ \\
\hline $\mathrm{N}=$ & 3363 & 7270 \\
\hline
\end{tabular}

Source : INPI Historical Database

Percentage of granted patents.

Improvement $\mathrm{p}$. and addition certificates

included. Only for patentees whose place

is known

\section{Table 2}

Patents by duration (1791-1839)

Patents for invention

\begin{tabular}{|c|c|c|c|}
\hline Decade & $1791-1819$ & $1820-1829$ & $1830-1839$ \\
\hline 5 years & $57,41 \%$ & $55,25 \%$ & $57,73 \%$ \\
\hline 10 years & $20,65 \%$ & $26,18 \%$ & $24,44 \%$ \\
\hline \multirow[t]{2}{*}{15 years } & $21,94 \%$ & $18,57 \%$ & $17,83 \%$ \\
\hline & $100,00 \%$ & $100,00 \%$ & $100,00 \%$ \\
\hline $\mathrm{N}=$ & 1080 & 1276 & 2983 \\
\hline \multicolumn{4}{|c|}{ Patents for importation } \\
\hline Decade & $1791-1819$ & $1820-1829$ & $1830-1839$ \\
\hline 5 years & $28,57 \%$ & $23,13 \%$ & $22,33 \%$ \\
\hline 10 years & $32,14 \%$ & $41,88 \%$ & $41,19 \%$ \\
\hline \multirow[t]{2}{*}{15 years } & $39,29 \%$ & $35,00 \%$ & $36,48 \%$ \\
\hline & $100,00 \%$ & $100,00 \%$ & $100,00 \%$ \\
\hline $\mathrm{N}=$ & 112 & 160 & 318 \\
\hline
\end{tabular}

Source : INPI Historical Database 
The difference of total amounts is due to missing data relative to duration.

\section{Chart 1}

Patents and certificates of addition granted in France (1791-1870)

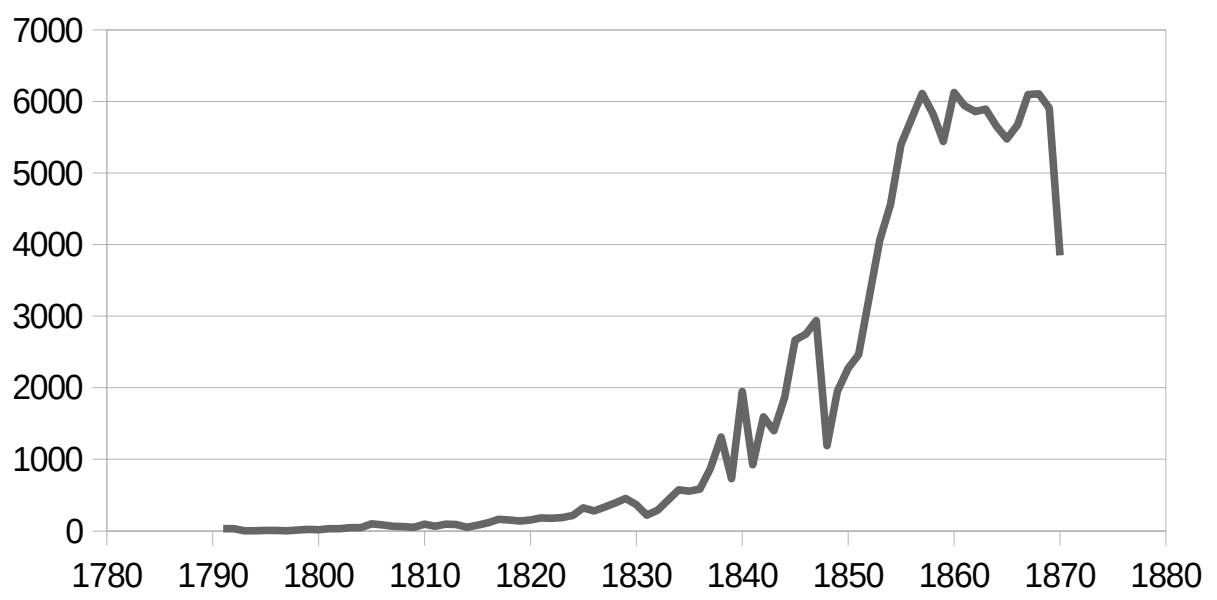




\section{Chart 2}

Patents for invention by industries

(1791-1819)

$0,00 \% \quad 10,00 \% \quad 20,00 \% \quad 30,00 \%$

01. Agriculture

03. Railways

05. Mechanical industry

07. Building

09. Household Equipment

11. Weapons

13. Ceramic Industry

15.Lighting - Heating - Cooling industry

17. Industrial Arts

19.Surgery and Medicine

1791-1819 1820-1829 1830-1839 


\section{Chart 3}

Number of patents for invention for one patent for importation

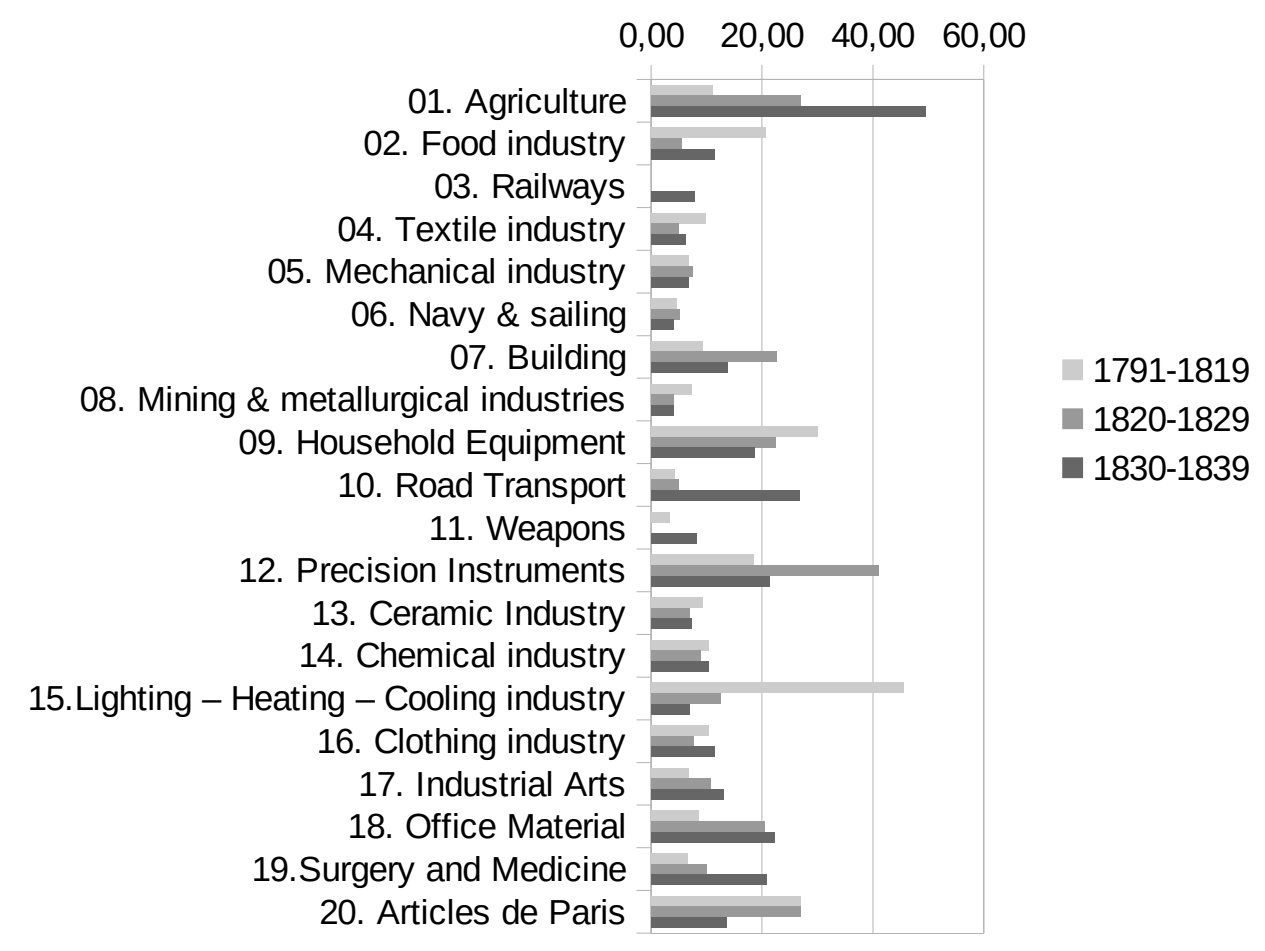

